Cochrane Database of Systematic Reviews

\title{
Massage therapy for people with HIV/AIDS (Review)
}

Hillier SL, Louw Q, Morris L, Uwimana J, Statham S

Hillier SL, Louw Q, Morris L, Uwimana J, Statham S.

Massage therapy for people with HIV/AIDS.

Cochrane Database of Systematic Reviews 2010, Issue 1. Art. No.: CD007502.

DOI: 10.1002/14651858.CD007502.pub2.

www.cochranelibrary.com 
TABLE OF CONTENTS

HEADER 1

ABSTRACT

PLAIN LANGUAGE SUMMARY

BACKGROUND

OBJECTIVES

METHODS

RESULTS

Figure 1.

Figure 2.

Figure 3.

Figure 4.

Figure 5.

DISCUSSION

AUTHORS' CONCLUSIONS

ACKNOWLEDGEMENTS

REFERENCES

CHARACTERISTICS OF STUDIES

DATA AND ANALYSES

Analysis 1.1. Comparison 1 MT vs control, Outcome 1 Quality of life.

Analysis 1.3. Comparison $1 \mathrm{MT}$ vs control, Outcome $3 \mathrm{CD} 4$ count (cells/ml).

Analysis 1.4. Comparison 1 MT vs control, Outcome 4 Natural killer cell count.

SOURCES OF SUPPORT 
[Intervention Review]

\section{Massage therapy for people with HIV/AIDS}

Susan L Hillier ${ }^{1}$, Quinette Louw ${ }^{2}$, Linzette Morris², Jeanine Uwimana ${ }^{3}$, Sue Statham²

${ }^{1}$ Centre for Allied Health Evidence, University of South Australia (City East), Adelaide, Australia. ${ }^{2}$ Faculty of Health Science, Stellenbosch University, Cape Town, South Africa. ${ }^{3}$ Faculty of Health Science, University of Western Cape, Cape Town, South Africa

Contact address: Susan L Hillier, Centre for Allied Health Evidence, University of South Australia (City East), North Terrace, Adelaide, SA, 5000, Australia.Susan.Hillier@unisa.edu.au.

Editorial group: Cochrane HIV/AIDS Group.

Publication status and date: New, published in Issue 1, 2010.

Citation: Hillier SL, Louw Q, Morris L, Uwimana J, Statham S. Massage therapy for people with HIV/AIDS. Cochrane Database of Systematic Reviews 2010, Issue 1. Art. No.: CD007502. DOI: 10.1002/14651858.CD007502.pub2.

Copyright ( 2010 The Cochrane Collaboration. Published by John Wiley \& Sons, Ltd.

\section{A B S T R A C T}

\section{Background}

Infection with human immunodeficency virus (HIV) and acquired immunodeficency syndrome (AIDS) is a pandemic that has affected millions of people globally. Although major research and clinical initiatives are addressing prevention and cure strategies, issues of quality of life for survivors have received less attention. Massage therapy is proposed to have a positive effect on quality of life and may also have a positive effect on immune function through stress mediation.

\section{Objectives}

The objective of this systematic review was to examine the safety and effectiveness of massage therapy on quality of life, pain and immune system parameters in people living with HIV/AIDS.

\section{Search methods}

A comprehensive search strategy was devised incorporating appropriate terms for HIV/AIDS, randomised controlled trials (RCTs), massage therapy and the pertinent measures of benefit. All electronic databases identified were searched in November 2008, including Cochrane Group Trials Register, Cochrane Central Register of Controlled Trials (CENTRAL), MEDLINE, EMBASE, SCIENCE CITATION INDEX, AIDSLINE, AIDSearch, CINAHL, HEALTHSTAR, PsycLIT, AMED, Current Contents, AMI, NLM GATEWAY, LILACS, IndMed, SOCIOFILE, SCI, SSCI, ERIC and DAI. We also reviewed relevant published and unpublished conference abstracts and proceedings and scrutinised reference lists from pertinent journals. There were no language or date restrictions.

\section{Selection criteria}

Studies were identified by two reviewers based on trial design (RCTs) and participants (ie, people of any age with HIV/AIDS, at any stage of the disease) who had undergone an intervention that included massage therapy for the identified aims of improving quality of life and activity and participation levels, improving immune function, reducing pain and improving other physiological or psychological impairments.

\section{Data collection and analysis}

Two reviewers independently identified included studies and extracted relevant data. Two other reviewers independently reviewed the included studies for risk of bias. All data and risk of bias judgements were entered into Revman (v5) and meta-analyses were conducted where appropriate.

\section{Main results}

Twelve papers were identified, from which four were included. The remaining eight papers were excluded predominantly due to inappropriate methodology. The four included studies were highly clinically heterogenous, investigating a range of age groups (ie, children, 
adolescents and adults) across the disease spectrum from early HIV through late-stage AIDS. The settings were either community or palliative care, and the outcome measures were a combination of quality of life and immunological function. The trials were judged to be at moderate risk of bias mostly because of incomplete reporting. For quality of life measures, the studies reported that massage therapy in combination with other modalities, such as meditation and stress reduction, are superior to massage therapy alone or to the other modalities alone. The quality of life domains with significant effect sizes included self-reported reduced use of health care resources, improvement in self-perceived spiritual quality of life and improvement in total quality of life scores. One study also reported positive changes in immune function, in particular CD4+ cell count and natural killer cell counts, due to massage therapy, and one study reported no difference between people given massage therapy and controls in immune parameters. Adverse or harmful effects were not well reported.

\section{Authors' conclusions}

There is some evidence to support the use of massage therapy to improve quality of life for people living with HIV/AIDS (PLWHA), particularly in combination with other stress-management modalities, and that massage therapy may have a positive effect on immunological function. The trials are small, however, and at moderate risk of bias. Further studies are needed using larger sample sizes and rigorous design/reporting before massage therapy can be strongly recommended for PLWHA.

\section{PLAIN LANGUAGE SUMMARY}

\section{Massage therapy for people with HIV/AIDS}

People living with HIV/AIDS may experience a lower quality of life due to complications of the disease. Massage therapy may help people by improving their overall health and their ability to deal with stress. We systematically investigated studies that have compared massage therapy with other forms of therapy or no therapy. We found four randomised controled trials that used massage therapy with children, adolescents or adults with HIV or late-stage AIDS. This review of the literature supports that massage therapy can benefit people with HIV/AIDS by improving quality of life, particularly if they receive the therapy in conjunction with other techniques, such as meditation and relaxation training, and provide more benefit than any one of these techniques individually. Furthermore, it may be that massage therapy can improve their body's ability to fight the disease; however, this is not yet convincingly proven. We recommend further studies be undertaken to investigate this question and recommend that in the meantime, people with HIV/AIDS use massage therapy to improve quality of life, provided they have clear goals and monitor their response to the therapy. 


\section{B A C K G R O U N D}

The human immunodeficency virus (HIV) and acquired immunodeficency syndrome (AIDS) is a pandemic that has affected millions of people globally. The 2007 AIDS epidemic update report from the World Health Organization (WHO) and the Joint United Nations Programme on HIV/AIDS (UNAIDS) highlights an estimated 33 million people living with HIV/AIDS (PLWHA) worldwide. More than two of three $(68 \%)$ adults and nearly $90 \%$ of children infected with HIV live in sub-Saharan Africa and more than three in four (76\%) cases result in AIDS death (UNAIDS/WHO 2007). Effective prevention strategies and availability of antiretroviral therapy (ART) have had some effect on the infection rate and number of deaths; however, AIDS remains a leading cause of mortality worldwide (UNAIDS 2008). Moreover, the high HIV infection rate and lack of good treatment options in some areas has clear negative affects on the quality of life of PWHA, notwithstanding changes in mortality rates.

\section{Description of the condition}

The human immunodeficiency virus is a lentivirus, a member of the retrovirus family that can lead to AIDS. The virus primarily infects vital cells in the human immune system, such as helper $T$ cells (specifically, CD4+ T cells), macrophages and dendritic cells. Infection with HIV leads to low levels of CD4+ T cells through three mechanisms: first by direct killing of infected cells; second, by increased rates of apoptosis in infected cells; and third, by killing infected CD4+ T cells by CD8 cytotoxic lymphocytes that recognise infected cells (Lawn 2004). When CD4+ T cell numbers decline below a critical level, cell-mediated immunity is lost and the body becomes progressively more susceptible to opportunistic infections. Eventually, most people with HIV develop AIDS. The mortality from AIDS is due primarily due to OIs such as tuberculosis (TB) or malignancies associated with the progressive failure of the immune system (Lawn 2004).

The main symptoms reported by PLWHA include the Ols, night sweats, fatigue, weight loss, Pneumocystis carinii pneumonia, Kaposi's sarcoma, cytomegalovirus lymphadenitis, depression, anxiety, poor sleep quality and pain. Peripheral neuropathic or nociceptive pain is a unique form of chronic pain that affects up to $60 \%$ of PLWHA. In Rwanda, for example, pain is the most prevalent symptom experienced by PLWHA (Uwimana 2005). The experience of these symptoms negatively affects physical ability and consequently reduces quality of life, as patients experience limitations in their activities and partcipation (Stjernswärd 2002, Eastbrook 2001, Ownby 2006, Gray 2007). The clinical course of HIV/ AIDS is changing due to medical and pharmacological discoveries, survival rates have increased and the picture of the disease is evolving as a chronic more than fatal condition.This change brings to the fore questions of longer-term management of symptoms, maintaining independence and quality of life for some individuals, while for others palliative care is required for an extended period.

\section{Description of the intervention}

The management of HIV/AIDS is usually in the form of pharmacological modalities, such as antiretroviral drugs, analgesic therapy and other pharmacological agents, and nonpharmacological modalities, such as massage, exercise and palliative care. The essence of these non-pharmacological modalities in HIV management is not intended to replace disease-modifying treatments such as ART, but to augment the comfort and support of individuals and families who are living with life-threatening illness. Therefore, different techniques and interventions used in symptom management, maintenance of independence and palliative care should be further explored. Pain and consequent physical disability is reportedly often undertreated in PLWHA (O'Neill 1993; Gwyther 2004). Findings of a recent study conducted in Rwanda also highlighted that impaired quality of life due to pain and disability was among the most unmet needs of PLWHA (Uwimana 2007). These findings signify the need to explore alternative intervention strategies to enhance the quality of life of PLWHA. Physical interventions, such as exercise, have been shown to be effective in improving physical function and psychological status for PLWHA (O'Brien 2004). One systematic review (Harding 2005) highlights that home palliative care and inpatient hospice care also significantly improved patient outcomes in the domains of pain and symptom control, anxiety, insight and spiritual well-being.

Therapeutic massage is another promising non-pharmacological intervention with reported benefits for PLWHA. The American Massage Therapy Association defines massage as the application of manual techniques and adjunctive therapies with the intention of positively affecting the heath and well being of the client (AMTA 2000). Massage therapy can include specific physical techniques or manual therapy, such as deep tissue work, Swedish massage, neuromuscular massage, shiatsu or acupressure (Rich 2002). Massage therapists generally hold certification or licensure to practice massage in those countries or jurisdictions where such qualifications are recognized. Professional training programs for massage therapists also vary from country to country and may be undertaken as part of a broader health professional training or as a profession in its own right (Rich 2002).

\section{How the intervention might work}

The reported effects of massage include pain relief, decreased levels of depression, improved immune function, improved blood flow and blood composition, reduced edema, and increased mobility of connective tissue, muscle and the nervous system (Field 2005, Goats 1994, Ironson 1996, Toups 1999). Massage is therefore potentially effective in improving the quality of life in patients suffering from chronic disorders (Muller-Oerlingausen 2007). Several studies have indicated that there is an increase in immune function following massage (Ironson 1996, Hernandez-Rief 2004). The proposed mechanisms for this effect are via alterations in biochemistry, such as reduced levels of cortisol and increased levels of serotonin and dopamine (Field 2005). What mediates these biochemical effects is not known but presumed to occur through stress reduction. With the myriad physical, psychological and biochemical effects reported in the literature, it is plausible that massage therapy could be useful in PLWHA in its ability to reduce symptoms such as pain and depression, improve immune system function and finally improve quality of life.

\section{Why it is important to do this review}

The prevalence of HIV/AIDS, and its catastrophic impact on the health and quality of life of PLWHA, necessitates significant investigations into safe and effective management strategies. In particular, HIV/AIDS is rife in developing and low-income countries where health budgets are small. Within this context an intervention which is low cost and can be taught to care-givers and families 
to administer holds great appeal. Massage has been identified as a suitable, low-cost intervention in the context of developing countries (Maulik 2009). The aim of this systematic review, therefore, is to ascertain the effectiveness of massage therapy on quality of life, pain and immune system function in PLWHA.

\section{O B J E C T IVES}

To examine the safety and effectiveness of massage therapy on quality of life, pain and immune system parameters in PLWHA

\section{METHODS}

\section{Criteria for considering studies for this review}

\section{Types of studies}

Randomised controlled trials (RCTs) comparing massage therapy with no therapy or another therapy modality. Controlled clinical trials (CCTs) were also considered if there were insufficient highquality RCTs.

\section{Types of participants}

All studies which included children, adolescents and adults with a diagnosis of HIV infection (all stages) were included. Studies of males only, females only, or both genders were included.

\section{Types of interventions}

Massage therapy was defined as systematic and scientific manipulation of body tissues performed with the hands of the therapist for the purpose of affecting the nervous and muscular systems and the general circulation, and was administered by a qualified health professional. The comparisons of interest were massage therapy compared to no therapy, sham or placebo therapy or another kind of therapy, such as exercise or relaxation training.

\section{Types of outcome measures}

The outcome measures considered included immunological and virological indicators and psychosocial measures.

Adverse events, including but not limited to injury, increased pain, increased neuropathic symptoms and immune suppression also were evaluated in included studies where reported.

\section{Primary outcomes}

The primary outcome measure was health-related quality of life (for example, the WHOQoL or EuroQoL), general health questionnaires (for example, the SF-36) and measures of restrictions of activity and participation.

\section{Secondary outcomes}

Secondary measures that were considered included:

- Immunological and virological indicators, including CD4 cell count (cells $/ \mathrm{mm}^{3}$ ) and viral load ( $\log _{10}$ copies),

- Measures of impairment, including pain, stiffness, anxiety and depression scales

- Other psychological and physiological measures not listed above.

\section{Search methods for identification of studies}

A comprehensive HIV/AIDS and RCT search strategy was provided via consultation with the HIV/AIDS Trials Search Coordinator (TSC) and was further refined.

\section{Electronic searches}

The following electronic databases were searched using the established keywords, with no date limits and no language restrictions.

Cochrane Group Trials Register

Cochrane Central Register of Controlled Trials (CENTRAL)

a) MEDLINE

b) EMBASE

c) SCIENCE CITATION INDEX

d) AIDSLINE, AIDSearch

e) CINAHL

f) HEALTHSTAR

g) PsycLIT

h) AMED

i) Current Contents

j) AMI

\section{k) NLM GATEWAY}

l) LILACS

m) IndMed

n) SOCIOFILE

l) SCI. SSCI. ERIC, DAI.

PubMed HIV Comprehensive Search Strategy

HIV string: HIV Infections[MeSH] OR HIV[MeSH] OR HIV[tw] OR hiv-1*[tw] OR hiv-2*[tw] OR hiv1[tw] OR hiv2[tw] OR HIV infect* ${ }^{*}[\mathrm{tw}]$ OR human immunodeficiency virus[tw] OR human immunedeficiency virus[tw] OR human immunodeficiency virus[tw] OR human immune-deficiency virus[tw] OR ((human immun*) AND (deficiency virus[tw])) OR acquired immunodeficiency syndrome[tw] OR acquired immunedeficiency syndrome[tw] OR acquired immuno-deficiency syndrome[tw] OR acquired immune-deficiency syndrome[tw] OR ((acquired immun*) AND (deficiency syndrome[tw])) OR "sexually transmitted diseases, viral"[MH]

Anti HIV string: "Antiretroviral Therapy, Highly Active"[MeSH] OR "Anti-Retroviral Agents"[MeSH] OR "Antiviral Agents"[MeSH:NoExp] OR ((anti) AND (HIV[tw])) OR antiretroviral*[tw] OR ((anti) AND (retroviral $\left.\left.{ }^{*}[\mathrm{tw}]\right)\right)$ OR HAART $[\mathrm{tw}] \quad$ OR ((anti) AND (acquired immunodeficiency[tw])) OR ((anti) AND (acquired immunedeficiency[tw])) OR ((anti) AND (acquired immuno- 
deficiency[tw])) OR ((anti) AND (acquired immune-deficiency[tw])) OR ((anti) AND (acquired immun*) AND (deficiency[tw]))

RCT Search strategy: (randomized controlled trial [pt] OR controlled clinical trial [pt] OR randomized controlled trials [mh] OR random allocation [mh] OR double-blind method [mh] OR singleblind method [mh] OR clinical trial [pt] OR clinical trials [mh] OR ("clinical trial" [tw]) OR ((singl* [tw] OR doubl* [tw] OR trebl* [tw] OR tripl* [tw]) AND (mask* [tw] OR blind* [tw])) OR (placebos [mh] OR placebo* [tw] OR random* [tw] OR research design [mh:noexp] OR (comparative study) OR (comparative studies) OR (evaluation studies) OR (evaluation study) OR follow-up studies [mh] OR prospective studies [mh] OR control* [tw] OR prospectiv* [tw] OR volunteer $\left.\left.^{\star}[\mathrm{tw}]\right)\right)$ NOT (animals [mh] NOT human [mh])

When using the above strategies in other databases the following were removed: [pt] ; [mh] ; [tw] ; [MeSH;NoEXP]

Examples of specific keywords used were: "massage", "massage therapy", "quality of life", "pain".

\section{Searching other resources}

The reference lists of all studies were checked.

Authors of significant papers were contacted to find other relevant published or unpublished studies.

The following online registers of ongoing trials on HIV and AIDS were searched:

\section{http://controlled-trials.com}

http://clinicaltrials.gov

A search for conference proceedings from relevant HIV/AIDS conferences and unpublished theses was undertaken.

\section{Data collection and analysis}

Where differences arose between the two reviewers in their determination of study inclusion, data extraction or quality evaluation, a third reviewer was consulted and consensus was reached via discussion.

\section{Selection of studies}

Two reviewers checked the studies identified by keyword search independently, by reading the abstracts to see if they met the inclusion criteria. All disagreements were resolved by consensus. If all the criteria were met, the study was retrieved in full and reviewed for methodological quality (risk of bias) and data extraction.

\section{Data extraction and management}

Data were entered into Revman (version 5) independently by two reviewers. Data included full citation details of the study, objectives, design, length, assessment time points, number and characteristics of participants (inclusion and exclusion criteria), description of intervention, outcome measures, withdrawals and adverse events.

\section{Assessment of risk of bias in included studies}

Two reviewers independently assessed the quality of the included studies for risk of bias using criteria recommended in the Cochrane Reviewers Handbook (Higgins and Green 2008, version 5, section
8) in four domains: sequence generation, allocation concealment, blinding of participants, personnel and outcome assessors, and incomplete outcome data (Table 8.5a). Studies were given an overall summary of the risk of bias for each important outcome across domains, as well as within and across studies using three levels: low, unclear or high risk of bias (Table 8.7a). The overall risk of bias was reported narratively in the context of any findings produced from a meta-analysis. Any conflict in evaluating risk was discussed with a third reviewer and consensus was reached.

\section{Measures of treatment effect}

Data were extracted and analysed to calculate relative risk, 95\% confidence intervals and individual and group effect sizes. This required the identification of the number of participants in each group in each trial and total number for dichotomous data and the number of participants plus the mean and standard deviations for each group for continuous data.

\section{Unit of analysis issues}

Studies with non-standard designs were considered; for example, cluster randomised trials were included if they were assessed as having a low risk of bias. Cross-over trials were considered only if they included an adequate washout period between phases or the authors provided an analysis of results for the first phase (ie, prior to cross-over).

\section{Dealing with missing data}

Authors were contacted to provide appropriate data for metaanalysis if these were not adequately reported in the retrieved paper.

Intention to treat analysis was considered as part of the risk of bias assessment and loss to follow up was recorded.

\section{Assessment of heterogeneity}

Statistical heterogeneity was assessed visually and using the 12 statistic.

Clinical heterogeneity (clinical and methodological diversity) was evaluated by the content experts on the review team.

\section{Assessment of reporting biases}

Reporting biases were avoided in part by the comprehensive search strategies and by having no date or language limits.

\section{Data synthesis}

Where possible, a meta-analysis was conducted with data using random effects, as the heterogeneity was expected to be relatively high. Where data were not available or were of excessive heterogeneity, a narrative summary of study results rather than a meta-analysis was produced.

\section{Subgroup analysis and investigation of heterogeneity}

If possible, sub-group analyses were to be performed to establish effectiveness among different groups (eg, males vs. females, children vs. adults or symptomatic vs. asymptomatic); however, there were insufficient studies to enable this. 


\section{Sensitivity analysis}

Sensitivity analyses may have been conducted to determine if particular studies skewed results where possible (eg, RCT vs. nonRCTs); however, this was not necessary.

\section{RES U L T S}

\section{Description of studies}

\section{Results of the search}

The search strategy resulted in 322 citations. The titles and abstracts were reviewed against the inclusion criteria, resulting in 12 full articles being retrieved.

\section{Included studies}

The12 retrieved citations were reviewed by two reviewers and subsequently four studies were agreed on for final inclusion (Birk 2000, Diego 2001, Shor-Posner 2006, Williams 2005). Two papers by Shor-Posner (Shor-Posner 2004 and Shor-Posner 2006) were retrieved but were found to report on the same trial so that only the latter, with the full outcome data, was included (see 'Characteristics of included studies' table).

\section{Design}

All four included studies were RCTs--two trials with two intervention arms and two trials with four. All studies included a control group that received usual or standard care that did not contain the intervention under investigation (Birk 2000, Williams 2005); a placebo intervention of friendly visits (Shor-Posner 2006) or an alternate plausible intervention of progressive muscular relaxation (Diego 2001).

\section{Participants}

Sample sizes ranged from 24 to 58 with a total of 178 participants across the four studies. The participants were adults (age range 27-50 years) in two studies (Birk 2000, Williams 2005), adolescents (aged 13-19 years) in one study (Diego 2001), or children (aged 2-8 years) in Shor-Posner 2006. Three studies investigated PLWHA who were diagnosed as infected with HIV but with no AIDS symptoms and non-hospitalised, and the fourth (Williams 2005) investigated people in late-stage AIDS.

\section{Setting}

Three studies were conducted in a community or home setting and one study (Williams 2005) was conducted in an AIDS-specific nursing facility. All studies were conducted in the United States except for Shor-Posner 2006, where the researchers were from the United States, but the actual participants resided in the Dominican Republic.

\section{Interventions}

All trials included one arm with massage therapy alone. This was administered for 12 weeks in three trials and four weeks in the fourth trial (Williams 2005), with an intensity of one, two or five times a week. Individual sessions ranged from 20 to 45 minutes. The massage techniques were variously described to include the upper or whole body and addressed major muscle groups for essentially relaxation responses (Swedish style). The studies all utilised trained massage therapists/health professionals.

The trials with greater than two arms investigated the effect of massage therapy alone and in combination with other modalities, such as aerobic exercise, biofeedback stress reduction (Birk 2000) and meditation (Williams 2005).

\section{Outcomes}

Two studies included quality of life measures (Birk 2000, Williams 2005), although only one (Diego 2001) included psychological measures for anxiety and depression. Birk 2000 measured health care utilisation and health perception as part of the quality of life measures. Three studies included physiological measures of disease, including CD4, CD8 and natural killer cell counts. No studies investigated pain, activity or participation restrictions, impairments or viral load.

\section{Excluded studies}

Seven studies were excluded, predominantly due to trial methodology issues. Three were of low design quality with no control group or were case series only or were secondary research papers: two were systematic reviews, one was a non-systematic review and one was a descriptive study. See table of Characteristics of excluded studies.

\section{Risk of bias in included studies}

The risk of bias across the four included studies was judged to be moderate, primarily due to unclear, unreported or negative responses. The judgements overall for the studies and for individual items in the individual studies are illustrated in Figure 1 and Figure 2 , respectively. Attempts to clarify missing or unclear information from the study authors were made, but only one author responded. 
Figure 1. Risk of bias graph: reviewers' judgements about each risk of bias item presented as percentages across all included studies.

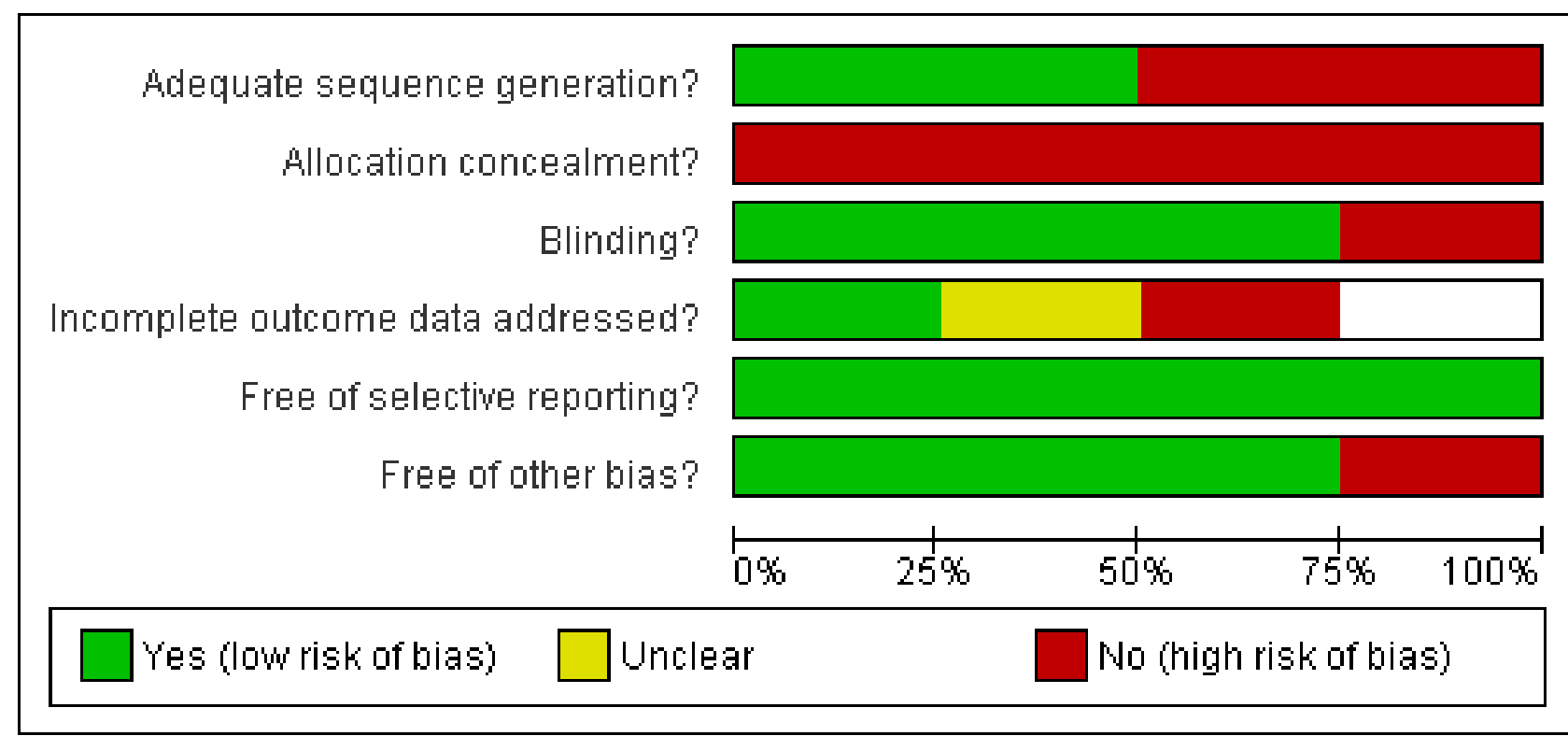

Figure 2. Risk of bias summary: reviewers' judgements about each item for each included study.

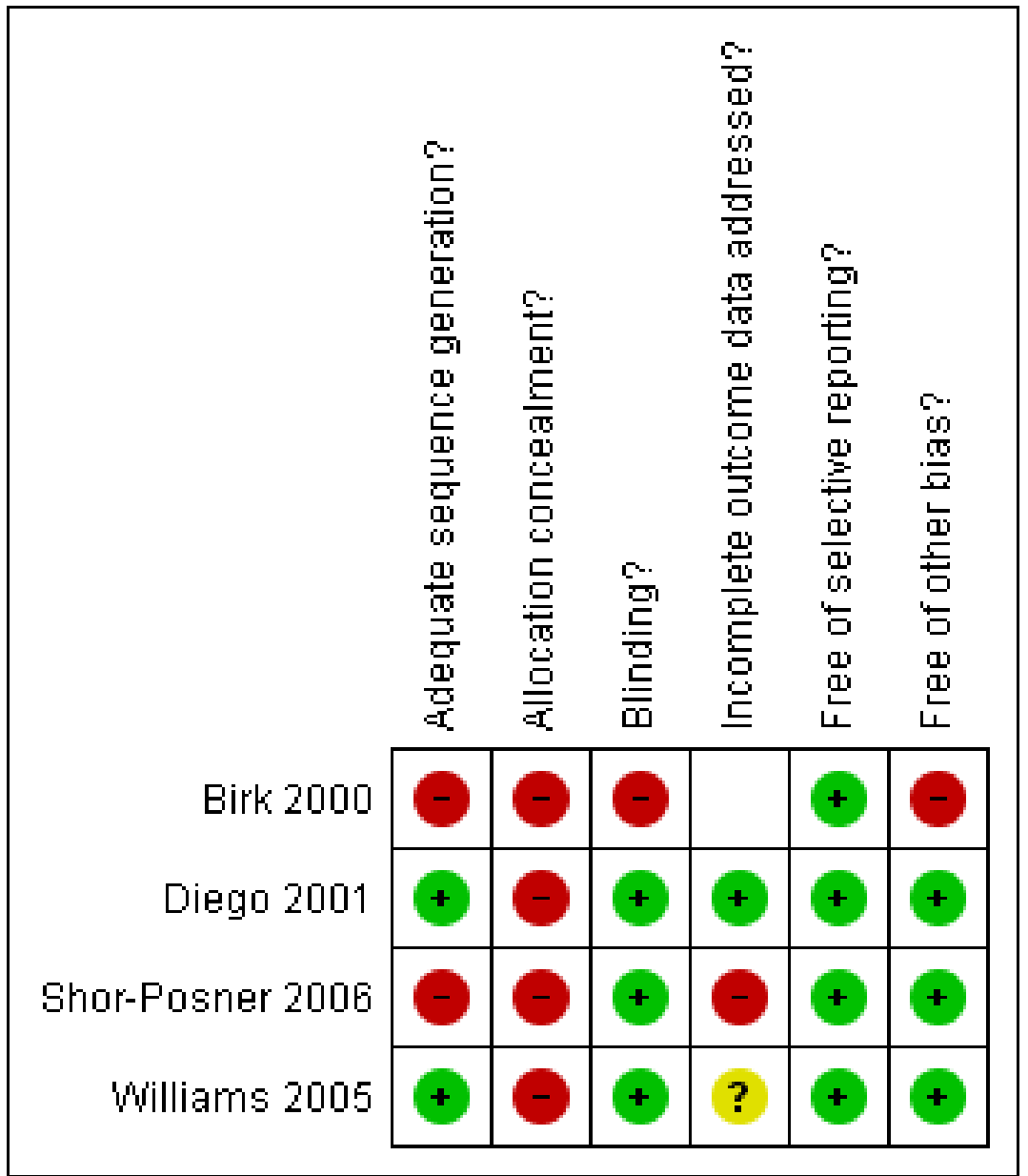




\section{Allocation}

Only two studies used adequate sequence generation (Diego 2001, confirmed via author contact, and Williams 2005). In the remaining studies the sequence generation process was not mentioned or was not clear. None of the studies reported that the allocation to the groups was concealed.

\section{Blinding}

Williams 2005 reported blinding of the assessors, and for ShorPosner 2006 it may be deduced that as the data were analysed in a laboratory by a machine, blinding of the assessor may have been implemented. Diego 2001 confirmed that the researchers conducting the assessments and blood assays were blinded. No studies blinded the subjects or therapists, or reported doing so; this is an expected finding because the nature of the physical intervention of massage cannot be concealed from the provider or the receiver, although the intent may be.

\section{Incomplete outcome data}

Incomplete data outcomes were inadequately addressed or unclear in all of the included studies, except for Diego 2001, which had no participants lost to the study. Williams 2005 had a disproportional loss to follow-up, but did, however, conduct intention-to-treat analysis and reported on the nature of the subjects who failed to complete. Shor-Posner 2006 did not report how it dealt with loss to follow-up.

\section{Selective reporting}

All studies were free of selective reporting.

\section{Other potential sources of bias}

Two studies (Williams 2005; Shor-Posner 2006) were considered free of other bias because they adequately reported on the baseline characteristics of the groups and the design of the study was appropriate. Diego 2001 confirmed that the study groups were not different at baseline. Birk 2000 did not compare baseline characteristics of groups.

\section{Effects of interventions}

Primary measures

Quality of life: In the two trials which investigated the primary outcome measure of quality of life, massage therapy in combination with other modalities, such as biofeedback stress reduction (Birk 2000) and meditation (Williams 2005) was reported to be superior to massage therapy alone, the other modalities alone or the control groups. The superior effects were demonstrated in self-reported improvement in quality of life ( $P=0.005$ for total quality of life score and $P=0.01$ for spiritual scores, Williams 2005), health perceptions and reducing health care utilisation $(P<0.05$, Birk 2000). Effect size calculations for each outcome (SMD, random effects) produced significant results for transcendent (spiritual) and total quality of life scores (both $\mathrm{P}<0.00001$ ) and health care utilisation $(P=0.04)$ in favour of massage therapy but not for health perception $(\mathrm{P}=0.19)$ (Figure 3$)$. The overall effect for the $\mathrm{Q}$ L L scores was significant $(\mathrm{P}=0.007)$ but the pooled results are inconclusive because heterogeneity was unacceptable at $12=89 \%$.

Figure 3. Forest plot of comparison: MT vs control, outcome: Quality of life - mixed.

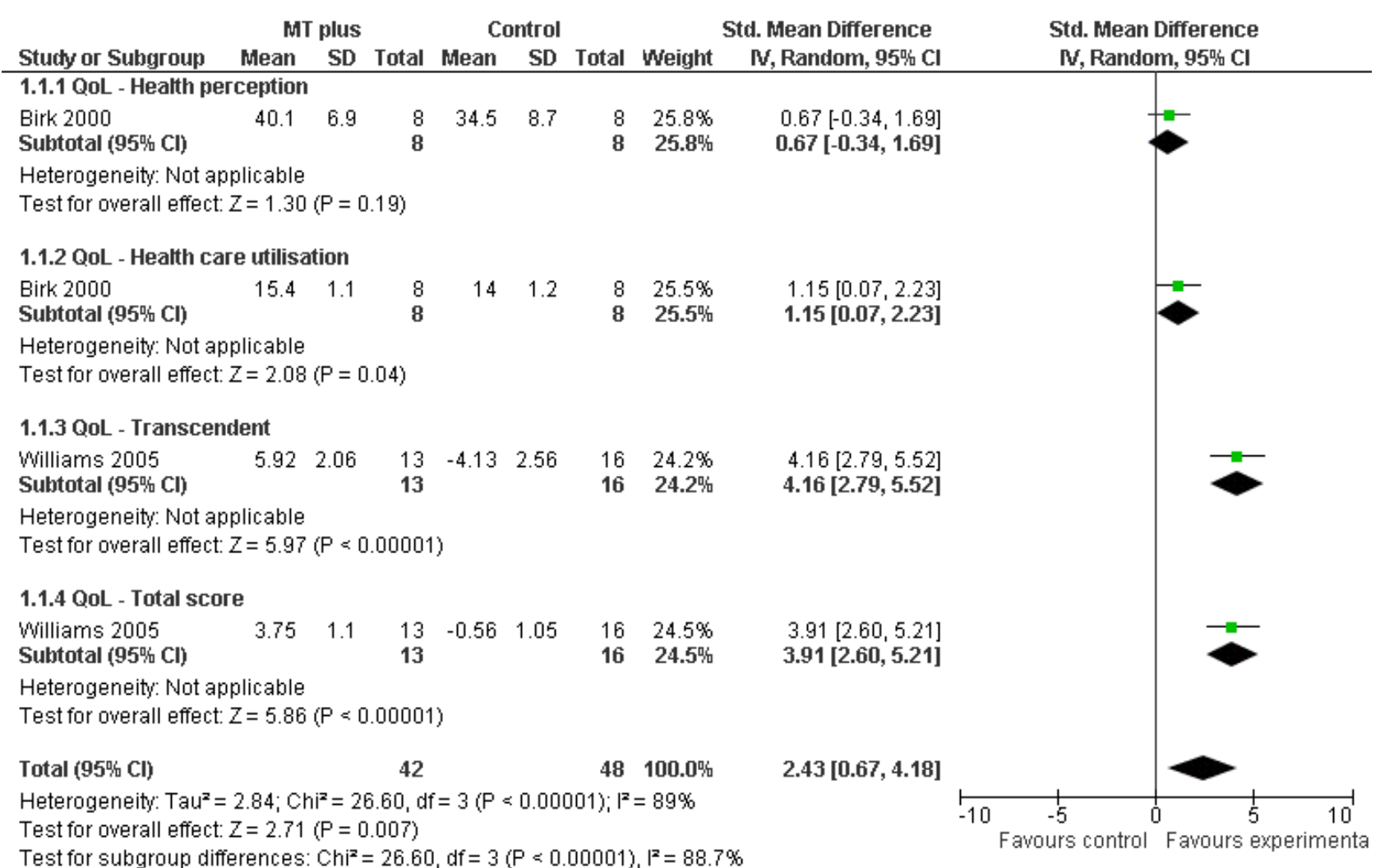


Activity and participation: No studies reported activity or participation outcome measures.

\section{Secondary measures}

Immunological function: In the three trials which investigated the effect of massage therapy on immunological function, massage therapy was reported to be superior in improving some immunological functions, for example increased number and markers of natural killer cells $(P<0.01)$; increased CD4 cell count $(P<0.05)$ (Diego 2001), and, in Shor-Posner 2006, more of the placebo group had a decline in CD4 cell count $(\mathrm{P}=0.03)$, older children receiving massage therapy had increased $C D 4+(P=0.04)$, and younger children with massage therapy had increased natural killer cell count $(P=0.05)$. The third trial (Birk 2000) did not show any significant differences between massage therapy and other modalities on immune function. Where appropriate data were able to be obtained, forest plots were constructed for CD4+ and natural killer cell counts, whether massage therapy was administered alone or in combination (Figure 4 and Figure 5). Meta-analysis using the available data from Birk 2000 was not appropriate due to the skewed nature of the data - transformation of the means and SD was not possible.

Figure 4. Forest plot of comparison: MT vs control, outcome: CD4 count (cells/ml).

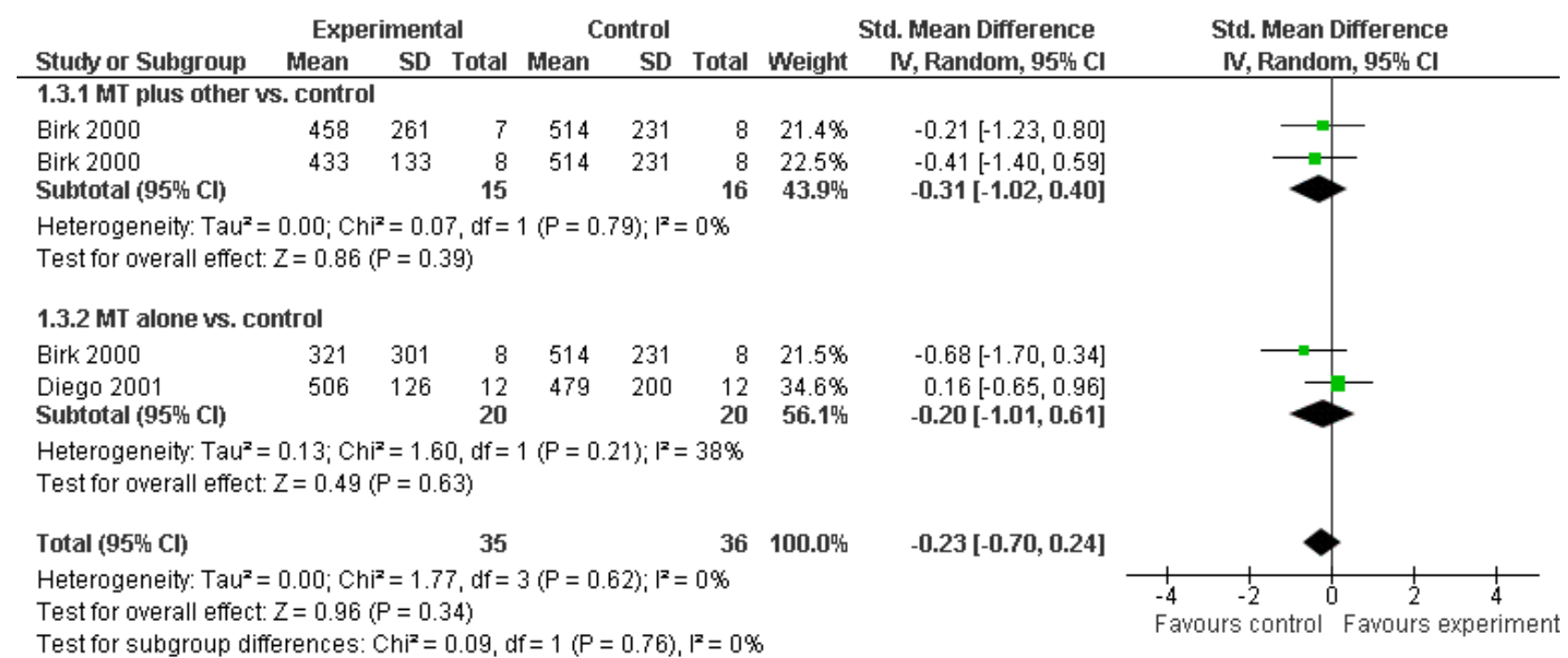

Figure 5. Forest plot of comparison: MT vs control, outcome: Natural killer cell count per $\mathrm{mm}^{3}$.

\begin{tabular}{|c|c|c|c|c|c|c|c|c|c|}
\hline \multirow[b]{2}{*}{ Stucły or Subgroup } & \multicolumn{3}{|c|}{ MT } & \multicolumn{3}{|c|}{ Control } & \multicolumn{2}{|c|}{ Std. Mean Difference } & \multirow{2}{*}{$\begin{array}{l}\text { Std. Mean Difference } \\
\text { N, Random, 95\% Cl }\end{array}$} \\
\hline & Mean & SD & Total & Mean & SD & Total & Weight & N, Random, 95\% Cl & \\
\hline Birk 2000 & 216 & 242 & 8 & 101 & 55 & 8 & $39.3 \%$ & $0.62[-0.39,1.63]$ & \\
\hline Diego 2001 & 160 & 56.5 & 12 & 135 & 49 & 12 & $60.7 \%$ & $0.46[-0.36,1.27]$ & \\
\hline Total $(95 \% \mathrm{Cl})$ & & & 20 & & & 20 & $100.0 \%$ & $0.52[-0.11,1.15]$ & \\
\hline \multicolumn{9}{|c|}{$\begin{array}{l}\text { Heterogeneity: } \operatorname{Tau}^{2}=0.00 ; \mathrm{Chi}^{2}=0.06, \mathrm{df}=1(\mathrm{P}=0.81) ; \mathrm{I}^{2}=0 \% \\
\text { Test for overall effect: } Z=1.61(P=0.11)\end{array}$} & $\begin{array}{llll}-4 & -2 & 0 & 2 \\
\text { Favours control } & \text { Favours }\end{array}$ \\
\hline
\end{tabular}

Pain or musculoskeletal impairments: No studies reported on these measures.

Anxiety and depression: Only one study (Diego 2001) investigated anxiety and depression levels and reported a significant positive effect of massage therapy compared with other modalities in reducing depression $(P<0.05)$. Data were not available for the calculation of effect sizes.

Adverse events: Only one study (Williams 2005) explicitly stated that no adverse events were recorded. Adverse effects or harm were not mentioned in the other three studies.

\section{DISCUSSION}

\section{Summary of main results}

Four trials were included in the review. Considering individual domains of quality of life, there were findings in favour of massage therapy in combination with other modalities,such as meditation and stress reduction, being superior to massage therapy alone or to the other modalities alone. The domains with significant effect sizes included a self-reported reduced use of health care resources, improvement in self-perceived spiritual quality of life and an overall improvement in total quality of life scores. These findings, however, were across two studies only. Individual studies also reported changes in immune function (in particular CD4+ and natural killer 
cell counts) in favour of massage therapy, and one study reported no difference between participants given massage therapy and controls; however, the effect sizes failed to reach significance (ie, were unable to be reasonably calculated).

\section{Overall completeness and applicability of evidence}

The small number of trials located and the small number of participants in each trial make any strong conclusions difficult. The pooled data for all domains of quality of life, although reaching significance, are difficult to interpret because the level of statistical heterogeneity was unacceptably high. There also was a high level of clinical heterogeneity among the studies in terms of age groups (children, adolescents and adults), stages of HIV/AIDS (early HIV and late-stage AIDS), intensity or dosage of massage therapy (from four weeks to 12 weeks and from one to five times per week) and outcomes measures (differing quality of life measures and tests of immune function). Incomplete data sets, despite contacting authors for completion, also hampered summary analyses. The small number of trials and participants precluded any sensitivity or sub-group analyses to evaluate the differential effects of these variables.The skewed nature of the CD4 and natural killer cell counts made those data inconclusive because transformation was not possible before meta-analysis. Three of the four studies were conducted in the United States, which further limits the applicability of study findings to other countries. Therefore, overall there is some evidence for effectiveness but spread across a broad range of age groups and HIV/AIDS stages and for a range of benefits.

\section{Quality of the evidence}

Overall, the trials were appraised to be at moderate risk of bias. All categories of bias were acceptable for the majority of studies (13 of a possible 24 items across the four studies were judged to be low risk of bias), except for allocation concealment, which was not undertaken or not reported in all studies.

\section{Potential biases in the review process}

No potential biases were encountered in the review process.

\section{Agreements and disagreements with other studies or reviews}

The overall findings of this review reflect the general conclusions of most other studies: there appears to be a positive effect on the quality of life of PLWHA particularly when massage therapy is delivered as a package of care, and that there is limited and conflicting evidence about the effect of massage therapy on immunological status. There are no other systematic reviews solely of massage therapy for PLWHA and the extant literature has mainly consisted of small studies of low methodological quality.

Two systematic reviews have evaluated complementary therapies, of which massage therapy is considered a part, in relation to effects on PLWHA (Ozsoy 1999, Mills 2005). Both studies also reported that, despite the widespread use of complementary and alternative medicine (CAM) by PLWHA, there is a paucity of clinical trials and a low level of methodological quality. Both reviews found more evidence for the use of CAM in the 'care' rather than 'cure' of HIV/AIDS, meaning that the overall effect of CAM and therefore also of massage therapy, may lie mostly in improving quality of life. One (non-systematic) review article (Field 2005) concluded that massage therapy does have physiological stress-reduction effects for a broad spectrum of people by decreasing cortisol and increasing serotonin and dopamine.

In summary, the findings of this review are in agreement with other related studies in the literature.

\section{AUTHORS' CONCLUSIONS}

\section{Implications for practice}

Massage therapy may be recommended for PLWHA with low to moderate evidence to support its effectiveness in improving aspects of quality of life, in early and late stages, and for different age groups. Effectiveness appears to improve when massage therapy is combined with other modalities, such as meditation and stress management. It may be that the effects of massage therapy on relaxation responses are short lived and that combining it with other methods that promote long-term stress management offer the most benefits. Clear, appropriate and globally standardised outcome measures should be implemented to gauge the effect of massage therapy given the low to moderate level of evidence. The implications for policy-makers are that services which are multi-facetted to include massage therapy should be encouraged if explicitly monitored.

There is mixed evidence to support the use of massage therapy to improve immune function in PLWHA.

There is as yet no evidence to support the use of massage therapy to improve activity and participation levels or to reduce pain in PLWHA.

There is only limited evidence that massage therapy has no adverse or harmful effects.

\section{Implications for research}

Future trials investigating massage therapy alone and in conjunction with other modalities are warranted.

Such trials need to:

- Have sufficient power (participant numbers) to detect meaningful effects

- Employ rigorous methodology to reduce risk of bias; in particular, trials need to implement adequate randomisation processes, allocation concealment and account for loss to follow up

- Use measures of effects that are more universal to allow for meta-analysis and cover a range of domains from physiological through impairment, activity/participation levels and quality of life

- Incorporate participant satisfaction measures and explicit recording of adverse events

- Clearly establish the stage of HIV/AIDS of participants and therefore investigate at which stage or stages massage therapy is most effective

- Investigate aspects of dosage/intensity/timing/type of the massage therapy intervention

- Investigate massage therapy in combination with other modalities to ascertain packages of care

- Analyse the cost-effectiveness of massage therapy and 
- Investigate the feasibility and effectiveness of massage therapy in developing countries, where HIV/AIDS is highly prevalent and where cultural beliefs and practices may have an influence.

\section{ACKNOWLEDGEMENTS}

The authors wish to acknowledge staff from the South Africa Cochrane Centre and Professor Jean Nachega (Stellenbosch University) for expert advice during the review process. 


\section{RE F E R E N C E S}

\section{References to studies included in this review}

Birk 2000 \{published data only\}

* Birk T, McGrady A, MacArthur R, Khuder S. The effects of massage therapy alone and in combination with other complementary therapies on immune system measures and quality of life in Human Immunodeficiency Virus. The Journal of Alternative and Complementary Medicine 2000;6(5):405-414.

\section{Diego 2001 \{published data only\}}

* Diego M, Field T, Hernandez-Reif M, Shaw K, Friedman L, Ironson G. HIV adolescents show improved immune function following massage therapy. Intern J Neuroscience 2001;106:35-45.

\section{Shor-Posner 2006 \{published data only\}}

* Shor-Posner G, Hernandez-reif M, Miguez M, Fletcher M, Quintero N, Baez J, Perez-then E, Soto S, Mendoza R, Castillo R, Zhang G. Impact of a Massage therapy clinical trial on immune status in young Dominican children infected with HIV-1. The Journal of Alternative and Complementary Medicine 2006;12(6):511-516.

\section{Williams 2005 \{published data only\}}

* Williams A, Selwyn P, Liberti L, Molde S, Njike V, McCorkle R, Zelterman D, Katz D. A randomized controlled trial of meditation and massage effects on quality of life in people with late-stage disease: a pilot study. Journal of Palliative Medicine 2005;8(5):939-953.

\section{References to studies excluded from this review}

Field 2005 \{published data only\}

Field T, Hernandez-Riez M, Diego M, Schanberg S, Kuhn C. Cortisol decreases and serotonin increases following massage therapy. Journal of Neuroscience 2005;115:1397-1413.

\section{Gore-Felton 2003 \{published data only\}}

Gore-Felton C, Vosvick M, Power R, Koopman C, Ashton E, Bachmann M, Israelski D, Spiegel D. Alternative therapies: A common practice among men and women living with HIV. Journal of the Association of Nurses in AIDS Care 2003;14:17-27.

Henrikson 2001 \{published data only\}

Henrickson M. Clinical outcomes and patient perceptions of acupuncture and/or massage therapies in HIV-infected individuals. AIDS Care 2001;13:743-748.

\section{Ironson 1996 \{published data only\}}

Ironson G, Field T, Scafidi F, Hashimoto M, Kumar A, Patarca R, Fletcher MA, Price A, Gonclaves A, Burman I, Tetenman C. Massage is associated with the enhancement of the immune systems's cytotoxic capacity. International Journal of Neuroscience 1996;84:205-217.

Mills 2005 \{published data only\}

Mills E, Wu P, Ernst E. Complementary therapies for the treatment of HIV: in search of the evidence. International Journal of STD and AIDS 2005;16:395-402.
Ownby 2006 \{published data only\}

Ownby KK. Effects of ice massage on neuropathic pain in persons with AIDS. Journal of Association of Nurses AIDS Care 2006;17:15-22.

\section{Ozsoy 1999 \{published data only\}}

Ozsoy M, Ernst E. How effective are complementary therapies for HIV and AIDS? A systematic review. International Journal of STD and AIDS 1999;10:629-635.

\section{Additional references}

\section{AMTA 2000}

American Massage Therapy Association. Glossary of terms. http://www.amtamassage.org/about/terms.html accessed August 2008.

\section{Birk 2000}

Birk TJ, McGrady A, MacArthur RD, Khuder S. The effects of massage alone and in combination with other complementary therapies on immune system measures and quality of life in human immunodeficiency virus. Journal of Alter Complement Med 2000;6 (5):405-414

\section{Diego 2001}

Diego MA, Field T, Hernandez-Reif M, Shaw K, Friedman L, Ironson G. HIV adolescents show improved immune function following massage therapy. International Journal of Neuroscience 2001;106:35-45.

\section{Eastbrook 2001}

Eastbrook P, Meadway J. The changing epidemiology of HIV infection: new challenges for HIV palliative care. Journal of Royal Society of Medicine 2001;24:442-448.

\section{Field 2005}

Field T, Hernandez-Riez M, Diego M, Schanberg S, Kuhn C. Cortisol decreases and serotonin and dopamine increase following massage therapy. Journal of Neuroscience 2005;115:1397-1413.

\section{Goats 1994}

Goats GC. Massage- the scientific basis of an ancient art. Part 2 Physiological and therapeutic effects. British Journal of Sports Medicine 1994;28 (3):153-156.

\section{Gray 2007}

Gray G, Berger P. Pain in women with HIV/AIDS. Pain 2007;Nov Suppl 1:13-21.

\section{Gwyther 2004}

Gwyther L, Rawlinson F. Symptom control in palliative care: essential for quality of life. South Africa Medical Journal 2004;94 (6):437-454

\section{Harding 2005}

Harding R, Karus D, Easterbrooks P, Raveis VH, Higginson IJ, Marconi K. Does palliative care improve outcomes for patients 
with HIV/AIDS? A systematic review of the evidence. Sexually Transmitted Infection 2005;81:2-3.

\section{Hernandez-Rief 2004}

Hernandez-Rief M, Ironson G, Field T. breast cancer patients have improved immune and neuroendocrine functions following massage therapy. Journal of Psychosomatic Research 2004;57:45-52.

\section{Ironson 1996}

Ironson G, Field T, Scafidi F, Hashimoto M, Kumar A, Patarca R, Fletcher MA, Price A, Gonclaves A, Burman I, Tetenman C. Massage is associated with the enhancement of the immune systems's cytotoxic capacity. International Journal of Neuroscience 1996;84:205-217.

\section{Lawn 2004}

Lawn SD. AIDS in Africa: the impact of coinfection on the pathogenesis of HIV-1 infection. Journal of Infectious Diseases 2004;48:1-12.

\section{Maulik 2009}

Maulik PK, Darmstadt GL. Community-based interventions to optimise early childhood development in low resource settings. Journal of Perinatology 2009;29:531-542.

\section{Muller-Oerlingausen 2007}

Muller-Oerlingausen, B, Berg, C, Groll, W. The efficacy of slow stroke massage in depression. Psychiatr Prax 2007;34 Suppl 3:S305-308.

\section{O'Brien 2004}

O'Brien, K, Nixon, S, Glazier, R.H, Tynan, A.M. Progressive resistive exercise interventions for adults living with HIV/AIDS. Cochrane Database of Systematic Reviews 2004, Issue 4.

\section{O'Neill 1993}

ONeill W, Sherrard J. Pain in human immunodeficiency virus disease: A review. Journal of Pain 1993;54:3-14.

\section{Ownby 2006}

Ownby KK. Effects of ice massage on neuropathic pain in persons with AIDS. Journal of Association of Nurses AIDS Care 2006;17:15-22.

\section{CHARACTERISTICS OF STUDIES}

Characteristics of included studies [ordered by study ID]

\section{Rich 2002}

Rich GJ. Massage therapy:The evidence for practice. 1st Edition. Philadelphia: Elsevier, 2002.

\section{Shor-Posner 2004}

Shor-Posner G, Miguez M-J, Hernandez-Reif M, Perez-Then E, Fletcher M. Massage Treatment on HIV-1 infected Dominican children: A preliminary report on the efficacy of massage therapy to preserve the immune system in children without anti-retroviral medication. The Journal of Alternative and Complementary Medicine 2004;10:1093-1095.

\section{Stjernswärd 2002}

Stjernswärd J. Uganda: Initiating a government public health approach to pain relief and palliative care. Journal of Pain and Symptom Management 2002;24 (2):257-264.

\section{Toups 1999}

Toups DM. A healing touch: massage and HIV/AIDS. STEP Perspect 1999;99(3):3-4.

\section{UNAIDS 2008}

UNAIDS. Report on the global HIV/AIDS epidemic 2008: executive summary.. http://data.unaids.org/pub/ GlobalReport/2008/JC1511_GR08_ExecutiveSummary_en.pdf 2008.

\section{UNAIDS/WHO 2007}

UNAIDS/WHO. AIDS Epidemic Update Report 2007. http:// data.unaids.org/pub/EPISlides/2007/2007_epiupdate_en.pdf.

\section{Uwimana 2005}

Uwimana J, Struthers P. Met and unmet palliative care needs of people living with HIV/AIDS in Rwanda. Masters thesis. Physiotherapy Department, University of the Western Cape, South Africa.

\section{Uwimana 2007}

Uwimana J, Struthers P. Met and unmet palliative care needs of people living with HIV/AIDS in Rwanda. Journal of Social Aspects of HIV/AIDS 2007;4(1):575-587.

* Indicates the major publication for the study

\section{Birk 2000}

$\begin{array}{ll}\text { Methods } & \text { RCT (4 groups) } \\ \text { MT vs. MT+ XS vs. MT+ BFB vs. contro }\end{array}$

Participants 42 male and female adults (27-50); HIV+, no AIDS symptoms; non-hospitalised.

Interventions

Group 1: MT 12/52 1xpw for 45 min (Swedish type, whole body) $n=8$

Group 2: MT a/a plus aerobic exercise (supervised 2x pw) n=7 
Birk 2000 (Continued)

Group 3: MT a/a plus biofeedback stress reduction $1 \times p w n=8$

Group 4: Control - standard care (no MT) n=8

\begin{tabular}{ll}
\hline Outcomes & 6D QoL; CD4, CD8 and NKC counts; CD4/8 ratio. \\
\hline Notes & $\begin{array}{l}\text { MT+BFB favourably increases health perceptions and reduces health care utilisation }(p<0.05), \text { com- } \\
\text { pared to single/other modalities or control. No other significant findings. }\end{array}$
\end{tabular}

\section{Risk of bias}

\begin{tabular}{lll}
\hline Bias & Authors' judgement & Support for judgement \\
\hline $\begin{array}{l}\text { Adequate sequence gener- } \\
\text { ation? }\end{array}$ & High risk & Sequence generation was not specified. \\
\hline Allocation concealment? & High risk & Not reported \\
\hline $\begin{array}{l}\text { Blinding? } \\
\text { All outcomes }\end{array}$ & High risk & Not reported \\
\hline $\begin{array}{l}\text { Free of selective report- } \\
\text { ing? }\end{array}$ & Low risk & \\
\hline \begin{tabular}{l} 
Free of other bias? \\
\hline
\end{tabular} & High risk & Baseline comparison between groups not done. \\
\hline
\end{tabular}

Diego 2001

\begin{tabular}{|c|c|}
\hline \multirow[t]{2}{*}{ Methods } & RCT (2 groups) \\
\hline & MT vs. other \\
\hline Participants & 24 male and female adolescents (13-19); HIV+, no AIDS symptoms; outpatients. \\
\hline \multirow[t]{2}{*}{ Interventions } & Group 1: MT 12/52 2xpw for 20min (upper body in chair) $n=12$ \\
\hline & Group 2: Other - $12 / 52$ progressive muscular relaxation $2 x p w n=12$ \\
\hline Outcomes & STAI (anxiety); CES-D (depression); CD4, CD8 and NKC counts; CD4/8 ratio. \\
\hline Notes & $\begin{array}{l}\text { MT reduced depression ( } p<0.05) \text {; increased NKC number and marker }(p<0.01) \text {; increased CD4 }(p<0.05) \\
\text { compared to other modality. }\end{array}$ \\
\hline
\end{tabular}

\section{Risk of bias}

\begin{tabular}{lll}
\hline Bias & Authors' judgement & Support for judgement \\
\hline $\begin{array}{l}\text { Adequate sequence gener- } \\
\text { ation? }\end{array}$ & Low risk & Sequence generation relayed via email \\
\hline Allocation concealment? & High risk & Not reported or relayed via email \\
\hline $\begin{array}{ll}\text { Blinding? } \\
\text { All outcomes }\end{array}$ & Low risk & Of assessors \\
\hline
\end{tabular}


Diego 2001 (Continued)
Incomplete outcome data Low risk
living with HIV/AIDS. Cochrane Database of Systematic Reviews 2004,

addressed?

All outcomes

\begin{tabular}{lll}
\hline $\begin{array}{l}\text { Free of selective report- } \\
\text { ing? }\end{array}$ & Low risk & Most likely \\
\hline Free of other bias? & Low risk & Baseline characteristics for groups did not differ \\
\hline
\end{tabular}

Shor-Posner 2006

\begin{tabular}{ll}
\hline Methods & RCT \\
& MT vs. placebo \\
\hline Participants & 54 male and female children (2-8); HIV+, no AIDs symptoms; non-hospitalised. \\
\hline Interventions & Group 1: MT 12/52 2xpw for 20 min (various body areas) $n=22$ \\
& Group 2: placebo - friendly visit 2xpw for 20 min $n=25$ \\
\hline Outcomes & CD4, CD8 and NKC counts. \\
\hline Notes & More of placebo had decline in CD4 count $(p=0.03) ;$ older children with MT had increased CD4+ ( $p=0.04) ;$ \\
\hline
\end{tabular}

\section{Risk of bias}

\begin{tabular}{|c|c|c|}
\hline Bias & Authors' judgement & Support for judgement \\
\hline $\begin{array}{l}\text { Adequate sequence gener- } \\
\text { ation? }\end{array}$ & High risk & Sequence generation not stated. \\
\hline Allocation concealment? & High risk & Not reported \\
\hline $\begin{array}{l}\text { Blinding? } \\
\text { All outcomes }\end{array}$ & Low risk & $\begin{array}{l}\text { Assessor may have been blinded as data were analysed in a laboratory and } \\
\text { conducted by a machine }\end{array}$ \\
\hline $\begin{array}{l}\text { Incomplete outcome data } \\
\text { addressed? } \\
\text { All outcomes }\end{array}$ & High risk & Authors did not mention how they dealt with loss to follow-up \\
\hline $\begin{array}{l}\text { Free of selective report- } \\
\text { ing? }\end{array}$ & Low risk & \\
\hline Free of other bias? & Low risk & \\
\hline
\end{tabular}

Williams 2005

\begin{tabular}{ll}
\hline Methods & RCT \\
MT vs. MT+ meditation vs. meditation vs. control
\end{tabular}


Williams 2005 (Continued)

Participants 58 male and female adults; late stage AIDS with/out co-morbidities; hospitalised.

Interventions Group 1: meditation 4/52; $\mathrm{n}=13$

Group 2: MT 4/52 5xpw for 30 min (various body areas) $n=16$

Group 3: meditation a/a plus MT a/a $n=13$

Group 4: control - standard care (no MT or meditation) n=16

\begin{tabular}{ll}
\hline Outcomes & QoL - total score and spiritual sub-category. \\
\hline Notes & MT+ meditation superior to single modalities/control for improved QoL-transcendent and QoL-total \\
scores ( $\mathrm{p}=0.01$ and $\mathrm{p}=0.005$ respectively)
\end{tabular}

\section{Risk of bias}

\begin{tabular}{lll}
\hline Bias & Authors' judgement & Support for judgement \\
\hline $\begin{array}{l}\text { Adequate sequence gener- } \\
\text { ation? }\end{array}$ & Low risk & \\
\hline Allocation concealment? & High risk & Not reported \\
\hline $\begin{array}{ll}\text { Blinding? } \\
\text { All outcomes }\end{array}$ & Low risk & mentioned that assessor was blinded \\
\hline $\begin{array}{l}\text { Incomplete outcome data } \\
\text { addressed? }\end{array}$ & Unclear risk & $\begin{array}{l}\text { Although intention-to-treat analysis was conducted, there was a dispropor- } \\
\text { All outcomes }\end{array}$ \\
& $\begin{array}{l}\text { tionate loss to follow-up. } \\
\text { references }\end{array}$ \\
\hline $\begin{array}{l}\text { Free of selective report- } \\
\text { ing? }\end{array}$ & Low risk & Data and analyses 1 MT vs control \\
\hline \begin{tabular}{l} 
Free of other bias? \\
\hline
\end{tabular} & Low risk & \\
\hline
\end{tabular}

\section{Characteristics of excluded studies [ordered by study ID]}

\begin{tabular}{ll}
\hline Study & Reason for exclusion \\
\hline Field 2005 & Methodology - review (non-systematic) \\
\hline Gore-Felton 2003 & Methodology - descriptive only \\
\hline Henrikson 2001 & Methodology - case control, quasi-experimental \\
\hline Ironson 1996 & Methodology - no control group \\
\hline Mills 2005 & Methodology - systematic review \\
\hline Ownby 2006 & Methodology - repeated measures, n=1 design \\
\hline
\end{tabular}




\begin{tabular}{ll}
\hline Study & Reason for exclusion \\
\hline Ozsoy 1999 & Methodology - systematic review \\
\hline
\end{tabular}

\section{DATA AND ANALYSES}

\section{Comparison 1. MT vs control}

\begin{tabular}{|c|c|c|c|c|}
\hline Outcome or subgroup title & $\begin{array}{l}\text { No. of } \\
\text { studies }\end{array}$ & $\begin{array}{l}\text { No. of } \\
\text { partici- } \\
\text { pants }\end{array}$ & Statistical method & Effect size \\
\hline 1 Quality of life & 2 & 90 & $\begin{array}{l}\text { Std. Mean Difference (IV, Random, 95\% } \\
\text { CI) }\end{array}$ & $2.43[0.67,4.18]$ \\
\hline 1.1 QoL - Health perception & 1 & 16 & $\begin{array}{l}\text { Std. Mean Difference (IV, Random, 95\% } \\
\text { CI) }\end{array}$ & $0.67[-0.34,1.69]$ \\
\hline $1.2 \mathrm{QoL}$ - Health care utilisation & 1 & 16 & $\begin{array}{l}\text { Std. Mean Difference (IV, Random, 95\% } \\
\text { CI) }\end{array}$ & $1.15[0.07,2.23]$ \\
\hline 1.3 QoL - Transcendent & 1 & 29 & $\begin{array}{l}\text { Std. Mean Difference (IV, Random, 95\% } \\
\text { CI) }\end{array}$ & $4.16[2.79,5.52]$ \\
\hline 1.4 QoL - Total score & 1 & 29 & $\begin{array}{l}\text { Std. Mean Difference (IV, Random, 95\% } \\
\text { CI) }\end{array}$ & $3.91[2.60,5.21]$ \\
\hline $3 \mathrm{CD} 4$ count (cells/ml) & 2 & 71 & $\begin{array}{l}\text { Std. Mean Difference (IV, Random, 95\% } \\
\mathrm{CI})\end{array}$ & $-0.23[-0.70,0.24]$ \\
\hline 3.1 MT plus other vs. control & 1 & 31 & $\begin{array}{l}\text { Std. Mean Difference (IV, Random, 95\% } \\
\mathrm{Cl} \text { ) }\end{array}$ & $-0.31[-1.02,0.40]$ \\
\hline 3.2 MT alone vs. control & 2 & 40 & $\begin{array}{l}\text { Std. Mean Difference (IV, Random, 95\% } \\
\mathrm{CI} \text { ) }\end{array}$ & $-0.20[-1.01,0.61]$ \\
\hline 4 Natural killer cell count & 2 & 40 & $\begin{array}{l}\text { Std. Mean Difference (IV, Random, 95\% } \\
\mathrm{Cl} \text { ) }\end{array}$ & $0.52[-0.11,1.15]$ \\
\hline
\end{tabular}

Analysis 1.1. Comparison 1 MT vs control, Outcome 1 Quality of life.

\begin{tabular}{|c|c|c|c|c|c|c|c|}
\hline \multirow[t]{2}{*}{ Study or subgroup } & \multicolumn{2}{|c|}{ MT plus } & \multicolumn{2}{|c|}{ Control } & \multirow{2}{*}{$\begin{array}{c}\text { Std. Mean Difference } \\
\text { Random, } 95 \% \mathrm{CI} \\
\end{array}$} & \multirow[t]{2}{*}{ Weight } & \multirow{2}{*}{$\begin{array}{c}\text { Std. Mean Difference } \\
\text { Random, } 95 \% \mathrm{Cl}\end{array}$} \\
\hline & $\mathbf{N}$ & Mean(SD) & $\mathbf{N}$ & Mean(SD) & & & \\
\hline \multicolumn{8}{|l|}{ 1.1.1 QoL - Health perception } \\
\hline Subtotal ${ }^{\star \star \star}$ & 8 & & 8 & & & $25.84 \%$ & $0.67[-0.34,1.69]$ \\
\hline \multicolumn{8}{|l|}{ Heterogeneity: Not applicable } \\
\hline \multicolumn{8}{|l|}{ Test for overall effect: $Z=1.3(P=0.19)$} \\
\hline & & & & rs control -10 & -5 & 10 Favours & rimental \\
\hline
\end{tabular}




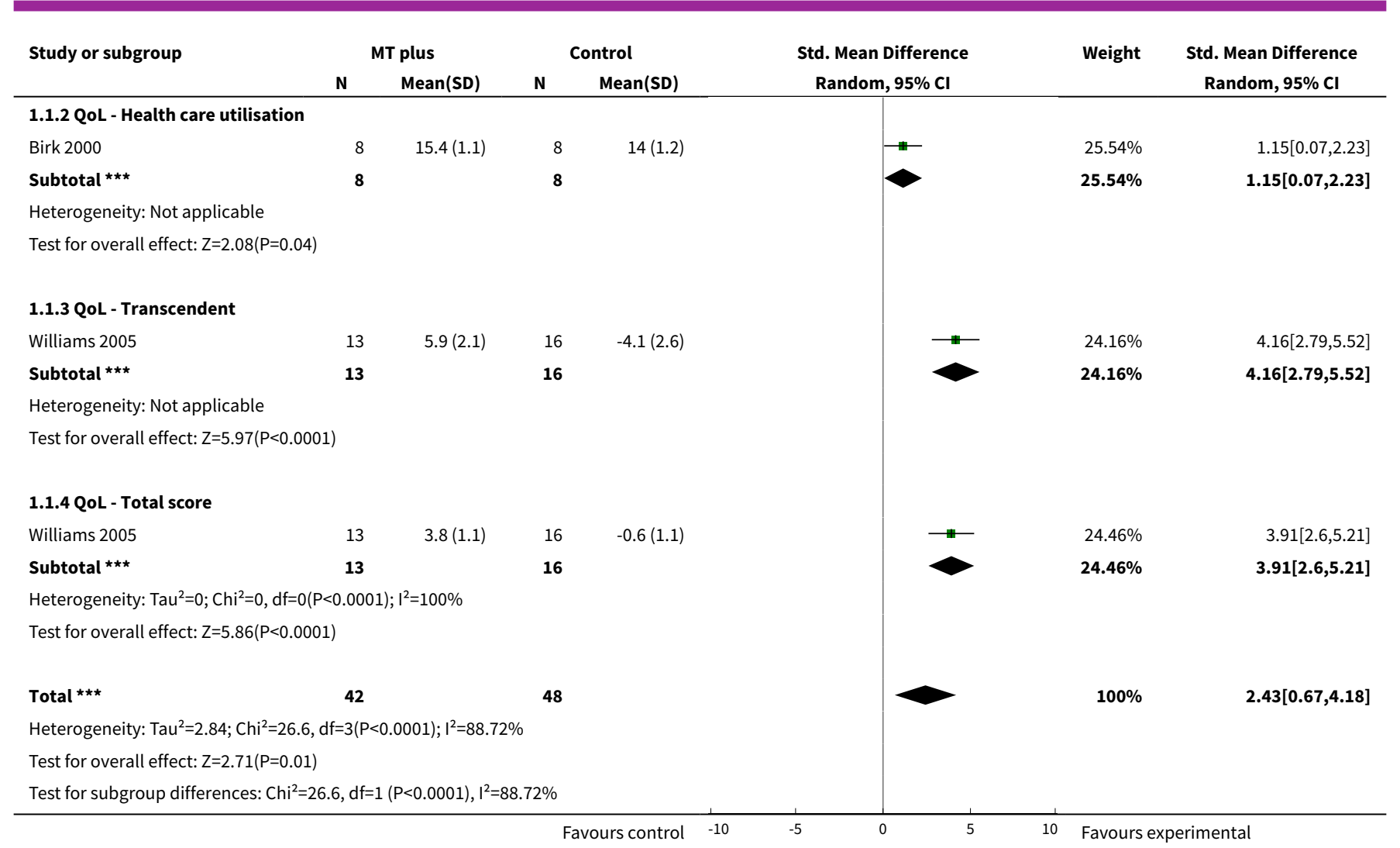

Analysis 1.3. Comparison 1 MT vs control, Outcome 3 CD4 count (cells/ml).

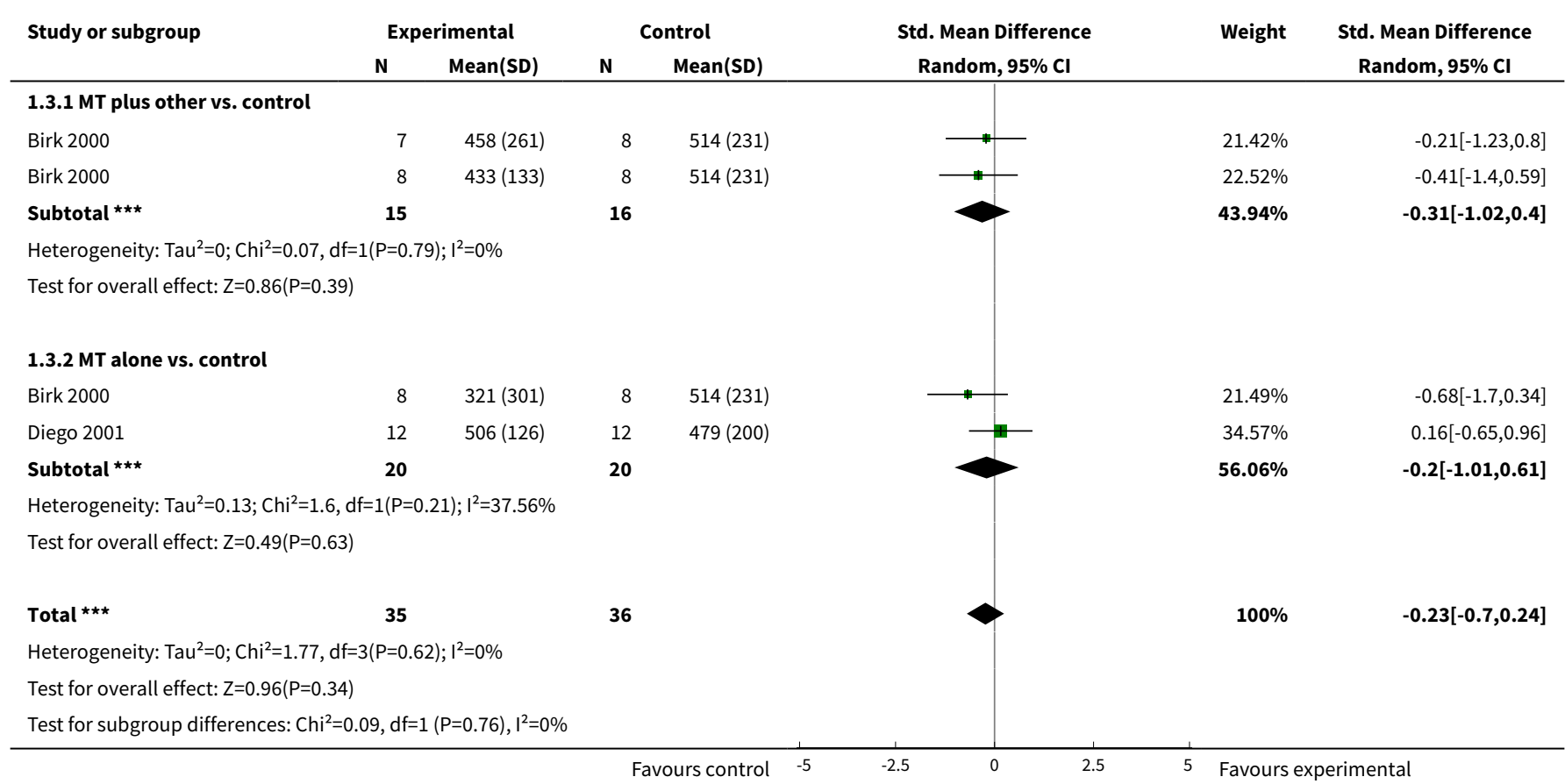


Analysis 1.4. Comparison 1 MT vs control, Outcome 4 Natural killer cell count.

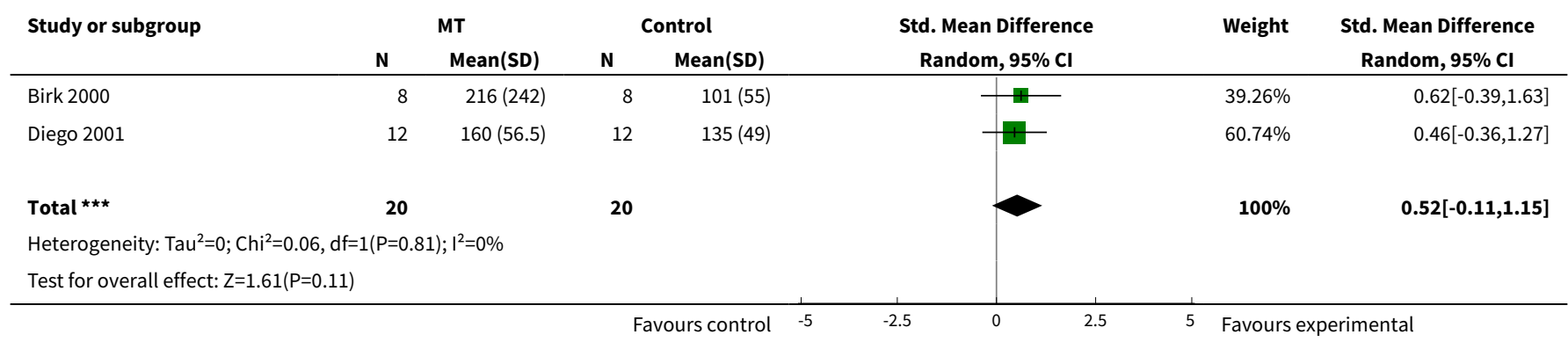

\section{HISTORY}

Protocol first published: Issue 4, 2008

Review first published: Issue 1, 2010

\begin{tabular}{lll}
\hline Date & Event & Description \\
\hline 3 November 2009 & Feedback has been incorporated & $\begin{array}{l}\text { Authors have added information in response to reviewers feed- } \\
\text { back. Ready for final approval. }\end{array}$ \\
\hline
\end{tabular}

\section{CONTRIBUTIONS OFAUTHORS}

Each author contributed specific sections of the review. Uwimana and Statham have content and clinical experience and contributed to the background, overall findings, and clinical content decision making. Hillier, Louw and Morris have experience in the conduct of systematic reviews and performed the process aspects of the review.

\section{DECLARATIONS OF INTEREST}

There are no known conflicts of interest.

\section{SOURCES OF SUPPORT}

\section{Internal sources}

- Nil, Not specified.

\section{External sources}

- Nil, Not specified.

\section{N DEX TERMS}

\section{Medical Subject Headings (MeSH)}

*Massage; *Quality of Life; Acquired Immunodeficiency Syndrome [psychology] [rehabilitation]; CD4-Positive T-Lymphocytes; HIV Infections [immunology] [psychology] [ ${ }^{\star}$ rehabilitation]; HIV-1; Randomized Controlled Trials as Topic

\section{MeSH check words}

Adolescent; Adult; Child; Humans 